\title{
PERFORMANCE OF LENTIL VARITIES AS INFLUENCED BY DIFFERENT Rhizobium INNOCULATIONS
}

\author{
M. A. Haque ${ }^{1}$, P. Bala ${ }^{2}$ and A. K. Azad ${ }^{2}$ \\ ${ }^{1}$ Lecturer, Lakhpur Shimulia College, Narosindhi \\ ${ }^{2}$ Ph.D. Fellow, Hajee Mohammad Danesh Science \& Technology University, Dinajpur. \\ Corresponding author: kbdpronay@yahoo.com
}

Key words: Yield, inoculation, lentil

\begin{abstract}
A field experiment was conducted at the farm of Bangladesh Agricultural University, Mymensingh during November 2009 to March 2010 to study the response of three lentil varieties (viz., BARI Masur-1, BARI Masur-2 and BARI Masur-3) to Rhizobium inoculations to yield. There were three Rhizobium inoculants (Rhizobium strain BINA L ${ }_{4}$, Rhizobium strain TAL 640, and mixed culture) with uninoculated control and urea @ $50 \mathrm{~kg} \mathrm{ha}^{-1}$. Phosphorus and potassium @ $26 \mathrm{~kg} \mathrm{P} \mathrm{ha}^{-1}$ from TSP and $33 \mathrm{~kg} \mathrm{~K} \mathrm{ha}^{-1}$ from MP were used as basal. It was observed that Rhizobium inoculation alone increased plant height, grain yield and crop residues yield of plant significantly compared to uninoculated control. Local inoculants BINA $\mathrm{L}_{4}$ performed better than the exotic culture TAL 640 in respect of yield. $50 \mathrm{~kg}_{\text {urea }} \mathrm{ha}^{-1}$ also recorded better results than control but not superior to any of the inoculation treatments. The highest seed $\left(1,565 \mathrm{~kg} \mathrm{ha}^{-1}\right)$ and crop residue yields $\left(3,303 \mathrm{~kg} \mathrm{ha}^{-1}\right)$ were recorded from the lentil variety BARIMasur-3 inoculated with mixed culture.
\end{abstract}

\section{Introduction}

Lentil (Lens culinaris Medik) is one of the most important pulse crops grown in Bangladesh. It belongs to the sub-family Papilionaceae under the family Leguminosae. In Bangladesh, it is popularly known as masur. Lentil grain contains 25\% protein, 0.7\% fat, and 59\% carbohydrate (Afzal et al., 1999). The lentil crop covers 33.33 percent of the total area of pulse in the country (BBS, 2012). Total production of lentil in Bangladesh, during 2010-2011 was 228568 tons from an area of 180574 hectare with an average yield of $1.2657 \mathrm{t} \mathrm{ha}^{-1}$ (BBS, 2012). Pulses are considered as the poor man's meat as they are the cheapest source of protein for the underprivileged people who cannot afford to buy animal proteins (Gowda and Kaul, 1982). The Stover of the plants together with husk popularly known as bhushi is highly protein concentrated feed for cattle, horse, pig and sheep (Tomar et al., 2000). Lentil being a legume crop can fix atmospheric nitrogen through root nodules by Rhizobium bacteria, which may reduce the pressure of nitrogenous fertilizer application to the crop. It is evident that pulse included in the cropping pattern helped to increase the organic matter in the soil (Islam, 1988).

Seed inoculation with appropriate Rhizobium sp is recommended to improve legume growth. They can reduce nitrogenous fertilizer use and protect environment. Response to Rhizobium inoculation to lentil depends on the soil type, crop cultivars and effectiveness of Rhizobium strains. Research work on contribution of Rhizobium inoculation on growth and yield of lentil is, however, scanty in this country. The selection of strain of Rhizobia particularly adapted to specific host plant is important. Judicious matching of Rhizobium stains with host plants and prudent use of large viable inocula prepared with these organisms is the only way to attain maximum nitrogen fixation and yields of leguminous crops. Keeping these in view, the investigation was undertaken to evaluate the effectiveness of three Rhizobium inoculants to lentil varieties in respect of yield.

\section{Materials and Methods}


Haque el al.

A field experiment was conducted during the winter (rabi) seasons of 2009 -2010 at the farm of the Department of Soil Science, Bangladesh Agricultural University, Mymensingh. The land was situated to the North East side of the farm and situated at latitude of $24.75^{\circ} \mathrm{N}$ and a longitude of $90.50^{\circ} \mathrm{E}$. The initial soil sample of the experimental field was collected and analyzed following standard procedures in the laboratory and presented in Table 1.

Table 1. Initial soil nutrient status of the experimental field

\begin{tabular}{l|c|c|c|c|c|c|c|c|c}
\hline Constituents & $\mathrm{pH}$ & $\mathrm{OC}(\%)$ & $\mathrm{OM}(\%)$ & $\begin{array}{c}\text { Total N } \\
(\%)\end{array}$ & $\begin{array}{c}\text { Available } \\
\mathrm{P}(\mathrm{ppm})\end{array}$ & $\begin{array}{c}\text { Exchangeable K } \\
\left(\mathrm{me}_{100 \mathrm{~g}^{-1} \text { soil) }}\right.\end{array}$ & Ca & $\mathrm{Mg}$ & $\mathrm{CEC}$ \\
\hline Experimental field & 6.7 & 1.085 & 1.875 & 0.089 & 11.95 & 0.12 & 0.12 & 3.95 & 18.50 \\
Critical level & 2.0 & 0.1 & 0.8 & 14 & 0.2 & 14 & 3.1 & 0.12 & \\
\hline
\end{tabular}

The experiment was laid out in split-plot design having four replications with 3 lentil varieties in main plots and 5 inoculation (no inoculation, BINA $\mathrm{L}_{4}$ as a local Rhizobium strain, TAL 640 as an Exotic Rhizobium strain, BINA $\mathrm{L}_{4}$ and TAL 640 as mixed culture and urea at the rate of $50 \mathrm{~kg} / \mathrm{ha}$ in sub plots The recommended dose of $26 \mathrm{~kg} \mathrm{P}, 33 \mathrm{~kg} \mathrm{~K}$ was applied as basal. The land was prepared by ploughing and cross- ploughing with the country plough followed by laddering uniformly. Fresh seeds of lentil were dipped in the respective culture broth of 5 days growth for two and half an hours. The seeds were dried in shade. The inoculated seeds of three inoculation treatments were randomly placed in the 5 unit plots of each main plot with spacing of $30 \mathrm{~cm}$ using $50 \mathrm{~kg}$ seed ha-1 sowing at 22 November, 2009 and harvested at 12 March, 2010. The harvested area of each plot was $4 \mathrm{~m} \times 2.5 \mathrm{~m}$. The crop was raised following recommended agronomic practices. Data on plant height from each plot 5 randomly selected plants were carefully measured and their mean values were determined. The yields were taken plot-wise by harvesting of each plot and then it was converted to hectare basis. The collected data were analyzed statistically using the analysis of variance technique with the help of computer package MSTAT and mean differences were adjudged by Duncan's Multiple Ranged Test (DMRT) (Gomez and Gomez, 1984).

\section{Results and Discussion}

\section{Plant height}

The effect of inoculation on plant height $(\mathrm{cm})$, grain yield $\left(\mathrm{kg} \mathrm{ha}^{-1}\right)$, crop residues yield $\left(\mathrm{kg} \mathrm{ha}^{-1}\right)$ and percent yield increase over control are presented in Table 2 and Table 3.

\section{Effect of Rhizobium inoculation}

The results showed that the Mixedculture gave the highest plant height $(11.49 \mathrm{~cm})$ at 40 days of sowing, the percent increase over uninoculated control being 8.8. At 60 days of sowing BINAL ${ }_{4}$ gave highest plants height $(18.03 \mathrm{~cm})$ and percent increases over control being 16. At 80 days of sowing recorded the highest plant height $(28.32 \mathrm{~cm})$, percent increase over control being 15.26. The maximum plant height $(34.30 \mathrm{~cm})$ was produced by mixed culture at 95 days of sowing, which was statistically superior to other treatments. Gwal et al. (1995) reported that the Rhizobium inoculants when applied resulted in the tallest plants and more branches/plant than the control. Similar results were obtained by Maurya and Sanoria (1986) in chickpea.

\section{Varietal response}

At vegetative stage (40 days of sowing), the maximum plant height was produced by the variety BARI Masur-3 $(11.12 \mathrm{~cm})$ followed by BARIMasur-1 $(11.09 \mathrm{~cm})$ and BARI Masur-2 $(10.93 \mathrm{~cm})$. Variety BARI Masur-3 gave tallest plant $(16.92 \mathrm{~cm})$ at 60 days of sowing, which was statistically superior to all other varieties. At 80 days of sowing, variety BARI Masur-2 gave the maximum plant height $(27.54 \mathrm{~cm})$ which was statistically similar with BARI Masur-3 $(27.40 \mathrm{~cm})$ but significantly higher than BARI Masur1 (Fig. 2). Variety BARI Masur-3 gave the maximum plant height $(33.26 \mathrm{~cm})$ at 95 days of sowing which was statistically similar with BARI Masur-2 $(32.83 \mathrm{~cm})$ but significantly higher than BARI Masur-1 $(31.23 \mathrm{~cm})$ The above results are in agreement with the findings of Sattar et al. (1995) who found that 
Rhizobium Innoculation in Lentil

seed inoculation with Bradyrhizobium increased plant height of five chickpea cultivars. Similar results were obtained by Fakir et al. (1988) in pigeonpea.

Table 2. Effect of Rhizobium inoculation and variety on seed and hay yield of lentil

\begin{tabular}{|c|c|c|c|}
\hline Factor & $\begin{array}{l}\text { Seed yield } \\
\left(\mathrm{kg} \mathrm{ha}^{-1}\right)\end{array}$ & Crop residue $\left(\mathrm{kg} \mathrm{ha}^{-1}\right)$ & $\begin{array}{l}\text { Yield increase over control } \\
\text { (\%) }\end{array}$ \\
\hline \multicolumn{4}{|l|}{ Inoculant } \\
\hline No inoculated & $894 d$ & $1,870 \mathrm{c}$ & - \\
\hline Rhizobium strain BINA $\mathrm{L}_{4}$ & $1,163 b$ & $2,537 b$ & 35.67 \\
\hline Rhizobium strain TAL 640 & $1,114 \mathrm{~b}$ & $2,520 \mathrm{~b}$ & 34.76 \\
\hline Mixed inoculation & $1,309 a$ & $2,965 a$ & 58.56 \\
\hline Urea@50kg N/ha $\left(\mathrm{U}_{50}\right)$ & $\begin{array}{l}960 \mathrm{c} \\
* *\end{array}$ & $\begin{array}{l}1,915 c \\
* *\end{array}$ & 2.41 \\
\hline \multicolumn{4}{|l|}{ Variety } \\
\hline BARIMasur-1 & $944 c$ & $2,199 b$ & \\
\hline BARIMasur-2 & $1,044 \mathrm{~b}$ & 2,404ab & \\
\hline \multirow[t]{2}{*}{ BARIMasur-3 } & $1,276 a$ & $2,482 a$ & \\
\hline & ** & * & \\
\hline
\end{tabular}

In a column, figures having common letter(s) do not differ significantly and those having different letter(s) differ significantly at 5 $\%(*)$ and $1 \%(* *)$ level of significance.

Table 3. The interaction effect of Rhizobium inoculation and variety on plant height, grain yield and hay yield of lentil

\begin{tabular}{|c|c|c|c|c|c|c|}
\hline \multirow{2}{*}{$\begin{array}{l}\text { Rhizobium } \times \\
\text { Variety } \\
\text { interaction }\end{array}$} & \multicolumn{4}{|c|}{ Plant height (cm) } & \multirow{2}{*}{$\begin{array}{l}\begin{array}{l}\text { Seed yield } \\
\left(\mathrm{kg} \mathrm{ha}^{-1}\right)\end{array} \\
*\end{array}$} & \multirow{2}{*}{$\begin{array}{l}\begin{array}{l}\text { Crop residue } \\
\left(\mathrm{kg} \mathrm{ha}^{-1}\right)\end{array} \\
*\end{array}$} \\
\hline & 40 days & 60 days & 80 days** & 95 days & & \\
\hline $\mathrm{V}_{1} \mathrm{R}_{0}$ & 10.63 & 15.55 & $20.95 \mathrm{~h}$ & 30.95 & $799 \mathrm{i}$ & $1,784 \mathrm{e}$ \\
\hline $\mathrm{V}_{1} \mathrm{R}_{\mathrm{L}}$ & 11.25 & 17.50 & 26.50fg & 30.00 & $1,004 \mathrm{e}$ & $2,334 d$ \\
\hline $\mathrm{V}_{1} \mathrm{R}_{\mathrm{E}}$ & 11.10 & 16.70 & $25.95 g$ & 30.05 & $979 f g$ & $2,309 d$ \\
\hline $\mathrm{V}_{1} \mathrm{R}_{\mathrm{M}}$ & 11.45 & 16.40 & $27.15 c-f$ & 33.90 & 1,118de & $2,722 \mathrm{bc}$ \\
\hline $\mathrm{V}_{1} \mathrm{U}_{50}$ & 11.00 & 15.75 & $26.10 \mathrm{~g}$ & 31.25 & 821hi & $845 \mathrm{e}$ \\
\hline $\mathrm{V}_{2} \mathrm{R}_{0}$ & 10.07 & 15.35 & $26.65 \mathrm{cfg}$ & 31.00 & 858hi & $1,954 \mathrm{e}$ \\
\hline$V_{2} R_{L}$ & 11.10 & 18.00 & 27.75bcd & 33.90 & 1,107de & $2,600 c$ \\
\hline$V_{2} R_{E}$ & 11.18 & 16.55 & $27.85 \mathrm{bcd}$ & 33.20 & 1,106de & $2,600 c$ \\
\hline $\mathrm{V}_{2} \mathrm{R}_{\mathrm{M}}$ & 11.45 & 16.80 & $28.70 \mathrm{ab}$ & 34.00 & $1,243 c$ & $2,869 \mathrm{~b}$ \\
\hline $\mathrm{V}_{2} \mathrm{U}_{50}$ & 10.85 & 15.45 & 26.75efg & 32.75 & $906 \mathrm{gh}$ & $1,995 \mathrm{e}$ \\
\hline $\mathrm{V}_{3} \mathrm{R}_{0}$ & 10.98 & 15.60 & $26.10 \mathrm{~g}$ & 31.80 & $1,023 \mathrm{ef}$ & $1,872 \mathrm{e}$ \\
\hline$V_{3} R_{L}$ & 11.45 & 18.60 & $28.00 \mathrm{bc}$ & 33.00 & $1,379 b$ & $2,675 b c$ \\
\hline$V_{3} R_{E}$ & 11.25 & 17.05 & 27.55cde & 33.55 & $1,256 c$ & $2,651 \mathrm{bc}$ \\
\hline $\mathrm{V}_{3} \mathrm{R}_{\mathrm{M}}$ & 11.57 & 17.30 & $29.10 \mathrm{a}$ & 35.00 & $1,565 a$ & $3,303 a$ \\
\hline $\mathrm{V}_{3} \mathrm{U}_{50}$ & 10.35 & 16.05 & $26.25 f g$ & 32.95 & $1,154 d$ & $1,906 \mathrm{e}$ \\
\hline CV (\%) & 5.80 & 2.79 & & 4.18 & 5.65 & 6.35 \\
\hline
\end{tabular}

In a column, figures having common letter(s) do not differ significantly and those having different letter(s) differ significantly at 5 $\%\left(^{*}\right)$ and $1 \%\left({ }^{*}\right)$ level of significance.

$\mathrm{R}_{0}=$ Uninoculated

$\mathrm{R}_{\mathrm{L}}=$ Rhizobium strain BINA L4

$\mathrm{R}_{\mathrm{E}}=$ Rhizobium strain TAL 640

$\mathrm{R}_{\mathrm{M}}=$ Mixed culture of BINA L4 and TAL 640

U50= Urea @ 50 kg N ha ${ }^{-1}$
$\mathrm{V}_{1}=$ BARI Masur- 1

$\mathrm{V}_{2}=$ BARI Masur -2

$\mathrm{V}_{3}=$ BARI Masur -3 


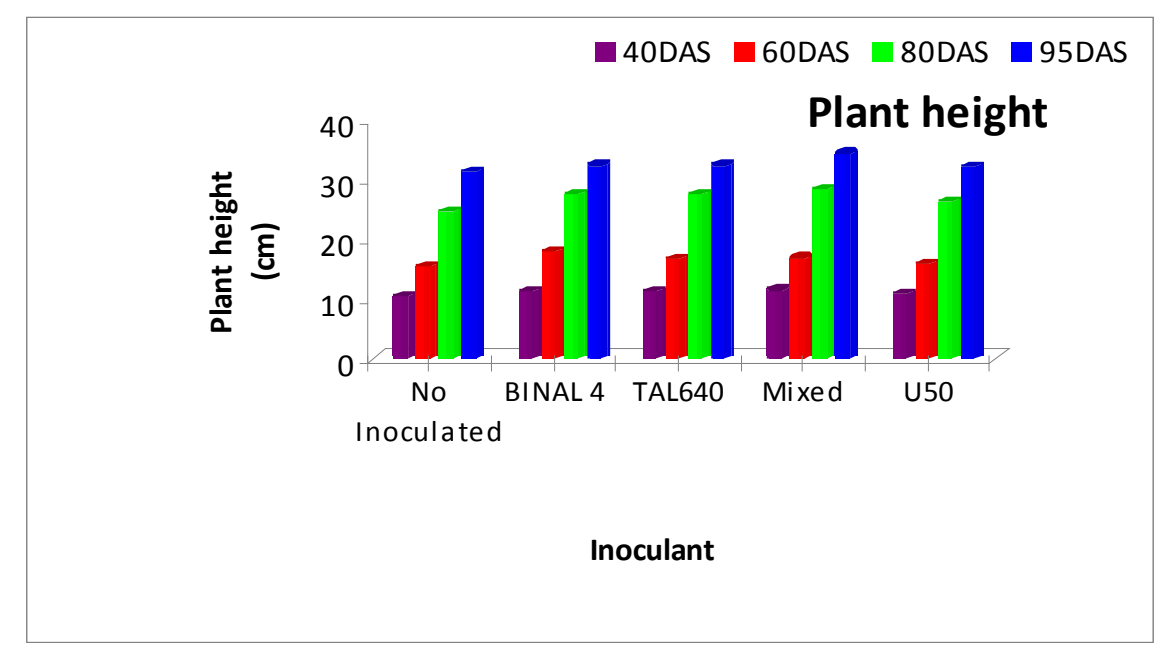

Figure 1. Effect of Rhizobium inoculation (upper) on plant height of lentil

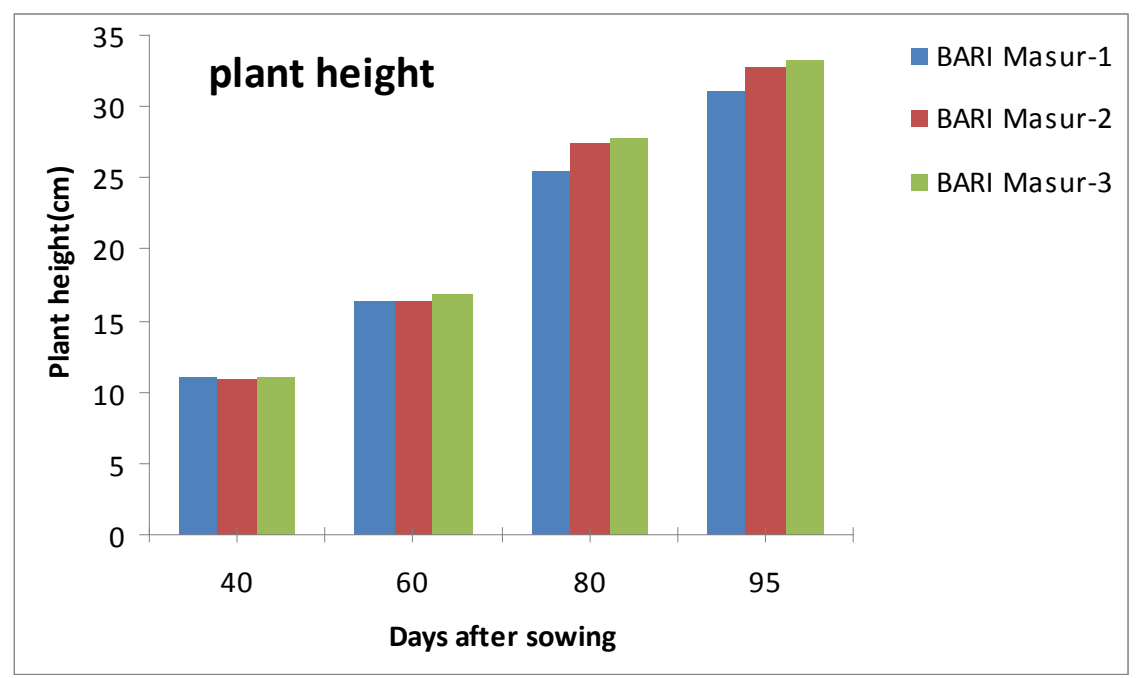

Figure 2. Effect of variety on plant height of lentil

\section{Interaction of Rhizobium and variety}

At 40 days of sowing the highest plant height $(11.57 \mathrm{~cm})$ was obtained by the treatment BARI Masur-3 $\mathrm{x}$ mixed culture $\left(V_{3} R_{M}\right)$, followed by interaction treatment $V_{3} R_{L}, V_{3} R_{E}, V_{2} R_{M}, V_{2} R_{E}, V_{2} R_{L} V_{1} R_{M}$, $\mathrm{V}_{1} \mathrm{R}_{\mathrm{L}}, \mathrm{V}_{1} \mathrm{R}_{\mathrm{E}}, \mathrm{V}_{1} \mathrm{U}_{50}$ (BARI Masur-1 $\times$ Urea @ $50 \mathrm{~kg} \mathrm{ha}^{-1}$ ) and $\mathrm{V}_{3} \mathrm{R}_{0}$ (Barimasur-3 $\times$ Uninoculated control) which was statistically similar (Table 1). The highest plant height $(18.60 \mathrm{~cm})$ was produced by the interaction of $V_{3} R_{L}$ at 60 days of sowing. The association $V_{3} R_{M}$, recorded the highest plant height $(29.10 \mathrm{~cm})$ at 80 days of sowing which was statistically superior to all other interaction treatments. The association $\mathrm{V}_{3} \mathrm{R}_{\mathrm{M}}$, recorded the highest plant height $(35.00 \mathrm{~cm})$ at 95 days of sowing which was statistically superior to all other interaction treatments. The above results are supported with the findings of some investigators. Lee and Yun (1989) reported on soybean when inoculated with Rhizobium stains increased plant height over uninoculated control. Similar results were obtained by Sattar and Ahmed (1995) in mungbean.

\section{Seed yield}


Rhizobium Innoculation in Lentil

Significant positive effect of Rhizobium inoculation on seed yield of lentil over non- inoculated control was observed (Table $2 \&$ Table 3). The mixed culture inoculation produced the highest seed yield (1,309 $\mathrm{kg} \mathrm{ha}^{-1}$ ), which was statistically superior to all other treatments, the percent increases (46\%) over uninoculated control.. Bremer et al. (1990) reported that the Rhizobium increased seed yield of lentil by up 135\%. Namedo et al. (1996) also observed that inoculation increased lentil seed yield by 17.5-23.2\% compared with no inoculation. Barimasur-3 recorded the highest grain yield (1,276 kg ha-1), which was statistically superior to both varieties. The highest grain yield $\left(1,565 \mathrm{~kg} \mathrm{ha}^{-1}\right)$ was recorded from the combination of BARI Masur-3 with mixed inoculation $\left(\mathrm{V}_{3} \mathrm{R}_{\mathrm{M} 0}\right)$, which was statistically superior to all other treatments(Table 3). Similar results were observed by Dziamba and Miroslaw (1994) in lentil.

\section{Crop Residue}

The highest crop residue $\left(2,965 \mathrm{~kg} \mathrm{ha}^{-1}\right)$ was recorded in mixed culture, which was significantly superior to all other treatments. It was higher than uninoculated control by 59\%. The above results indicated that there was significant beneficial effect of inoculation on crop residue compared to uninoculated control. Similar results were also obtained by Podder et al. (1989) in lentil. The highest crop residue $\left(2,482 \mathrm{~kg} \mathrm{ha}^{-}\right.$ $\left.{ }^{1}\right)$ was obtained by the variety BARI Masur-3, which was statistically superior to BARI Masur-1 (2,199 $\left.\mathrm{kg} \mathrm{ha}^{-1}\right)$ but similar to BARI Masur-2 $\left(2,404 \mathrm{~kg} \mathrm{ha}^{-1}\right)$. Similar results were found by Islam and Afandi (1980) in lentil. The interaction of $V_{3} R_{M}$ recorded the highest crop residue (3,303 $\mathrm{kg} \mathrm{ha}^{-1}$ ), which was significantly superior to all other treatments. The above results are similar with that of Bhuiya et al. (1986).

\section{Correlation}

The relationship between total number of nodules at 60 days of sowing and grain yield has been found out. The correlation coefficient $(r=0.6425)$ was found significant at $1 \%$ level of probability. The relation was positive i.e. increase in nodule number results in an increase in the seed yield of lentil. The statistical relationship between total number of nodules at 60 days and crop residues has been calculated and found positive The correlation coefficient $(r=0.858)$ was highly significant. The statistical relationship between nodule dry weight at 60 days and seed yield has been found positively correlated. The correlation coefficient $(r=0.665)$ was highly significant. The statistical relationship between total number of nodules at 60 days and crop residues has been found positively correlated. The correlation coefficient $(r=0.858)$ was highly significant. The statistical relationship b nodule dry weight at 60 days and crop residues has been positively correlated. The correlation coefficient $(r=0.900)$ was highly significant. The statistical relationship between grain yield and hay yield has been found positively correlated. The correlation coefficient $(r=0.775)$ was highly significant.

\section{Conclusion}

The present investigation suggested that lentil genotype BARI Masur-3 produced highest seed yield and crop residue. Rhizobium strain BINA L4 and TAL 640 were effective items in term of yield. A significant and positive correlation was observed between nodule number and nodule weight, crop residues and seed

yield; nodule weight, crop residue and seed yield. Further study is necessary to draw a definite conclusion.

\section{References}

Afzal, M. A., M. A. Bakr and M. L. Rahman. 1999. Lentil cultivation in Bangladesh. Lentil, Blackgram and Mungbean Development Pilot Project, Pulses Research Station, BARI, Gazipur-1701. 
Haque el al.

BBS. 2012. Yearbook of Agricultural Statistics of Bangladesh. Bangladesh Bureau of Statistics, Ministry of Planning, Government of the People's Republic of Bangladesh, Dhaka.

Bhuiya, Z. H., M. R. Islam, M. J. Uddin and M. S. Hoque.1986. Performance of some Rhizobium inoculations on blackgram (Vigna mungo). Bangladesh J. Agric. 11(4): 55-63.

Bremer, E., C. Kessel, L. Nelson, R. J. Rennie, D. A. Rennie and C. Van-Kessel. 1990. Selection of Rhizobium leguminosarum strains for lentil (Lens culinaris) under growth room and field conditions. Plant Soil. 121(1): 47-56.

Dziamba, S. and H. Microslaw.1994. Effect of inoculating lentil seeds with Rhizobium strains on yield. Biuletyn Instytutu Hodowli-i Aklimatyzacji Roslin. No. 189, 85-90:11.

Fakir, M. S. A., A. A. A. Mushi and S. M. M. Alam. 1998. Effects of Rhizobium inoculation, nitrogen and phosphorus on yield contributing characters of soybean. Bangladesh J. Agril. Sci. 15(2): 211-215.

Gomez, K. A. and A. A. Gomez. 1984. Statistical Procedures for Agric. Res. 2nd Edn. John Willey and Sons. New York. pp.207-215.

Gowda, C. L. L. and A. K. Kaul. 1982. Pulses in Bangladesh, BARI publication. 6 (1): 27-29.

Gwal, H. B., R. J. Tiwari and D. K. Gupta. 1995. Fertilizer management of lentil under rainfed conditions in Madhya prodesh. Lens Newsl. 22(1-2): 11-12.

Islam, R. and F. Afandi. 1980. Response of lentil cultivars to of Rhizobium inoculation and nitrogen fertilization. Lens. 7: 50-51.

Islam, M. S. 1988. Nutrient status of Bangladesh soils. Annual report for 1988. Bangladesh Agril. Res. Inst., Gazipur, Bangladesh. pp.82-85.

Lee, H. S. and S. H. Yun. 1989. Studies on the response of Rhizobium inoculation and nitrogen concentration on growth and yield of soybean cultivars. Korean J. Crop Sci. 34(4): 400-407.

Maurya, B. R. and C. L. Sanoria. 1986. Beneficial effects of coinoculating chickpea seed with Rhizobium , Azotobacter and Pseudomonas . Indian J. Agric. Sci. 56(6): 463-466.

Namdeo, S. L., S. C. Gupta and R. K. Joshi. 1996. Influence of rhizobial inoculation on nodulation and yield of lentil genotypes under rain fed conditions. LENS Newsletter. 23(1\& 2): 24-26.

Podder, A. K., M. A. Sattar and G. Marshed. 1989. Performance studies of some isolated native rhizobial inocula on the production and nodulation of lentil with or without nitrogen fertilizer. Proc. $6{ }^{\text {th }}$ Natl. Bot. Conf., Jan. 18-19. Abs. No. 43, p.23.

Podder, A. K. 1994. Performance of single and mixed rhizobial inoculafor nodulation and growth of lentil. LENS Newsl. 21 (1): 39-40.

Sattar M. A., M. A. Quader and S. K. A. Danso. 1995. Nodulation, nitrogen fixation and yield of chickpea as influenced by host cultivar and Bradyrhizobium stain differences. Soil Biol. Biochem. 27 (4/5): 725727.

Sattar, M. A. and S. U. Ahmed. 1995. Response of mungbean (Vigna radiata L. Wilczek) to inoculation with Bradyrhizobium as affected by phosphorus levels. Proc. Intl. Cong. Comm. IV. pp.419-423.

Tomar, S. K., P. Tripathi and A. L. Rajput. 2000. Effect of genotype, seeding method and diammonium phosphate on yield and protein and nutrient uptake of lentil (Lens culinaris L. Medik). Indian J. Agron. 45 (1): 148-152. 